\title{
Effects of a novel glucagon receptor antagonist (Bay 27-9955) on glucagon-stimulated glucose production in humans
}

\author{
K. F. Petersen ${ }^{1}$, J. T. Sullivan ${ }^{2}$ \\ ${ }^{1}$ Yale University School of Medicine, Department of Internal Medicine, New Haven, Connecticut, USA \\ ${ }^{2}$ Bayer Pharmaceuticals, West Haven, CT, USA
}

\section{Abstract}

Aims/hypothesis. To study the effects of a specific glucagon receptor antagonist (Bay 27-9955), on plasma glucose concentrations and rates of glucose production in response to hyperglucagonaemia in humans. Methods. The study was conducted as a two-dose [Low Dose Bay 27-9955 $70 \mathrm{mg},(n=6)$, High Dose Bay 27-9955 $200 \mathrm{mg},(n=8)$ ], double blind, placebo controlled, crossover study. Basal glucose production was measured after an overnight fast with $\left[6,6-{ }^{2} \mathrm{H}\right]$. At 0 min Bay 27-9955 or placebo was administeredand at $120 \mathrm{~min}$ an infusion of somatostatin $\left[0.1 \mu \mathrm{g} \cdot(\mathrm{kg} \cdot \mathrm{min})^{-1}\right]$, insulin $\left[24 \mathrm{pmol} \cdot\left(\mathrm{m}^{2} \cdot \min \right)^{-1}\right]$ and glucagon $\left[3 \mathrm{ng} \cdot(\mathrm{kg} \cdot \mathrm{min})^{-1}\right]$ was initiated.

Results. Basal plasma glucose concentrations were about $5 \mathrm{mmol} / \mathrm{l}$ and basal rates of glucose production were about $13 \mu \mathrm{mol} \cdot(\mathrm{kg} \cdot \mathrm{min})^{-1}$. During the hyperglucagonaemic period, plasma glucagon concentrations doubled to $100 \mathrm{pg} / \mathrm{ml}$, plasma glucose concentration increased by $75 \%$ to a peak of about
$10 \mathrm{mmol} / \mathrm{l}$ and glucose production doubled to about $23 \mu \mathrm{mol} \cdot(\mathrm{kg} \cdot \min )^{-1}(p<0.0001 \mathrm{vs}$ basal $)$. In the High Dose Group these effects of glucagon were markedly blunted, plasma glucose concentrations were $7.6 \pm 1.1 \mathrm{mmol} / \mathrm{l}(p=0.012 \mathrm{vs}$ placebo $)$ and rates of glucose production increased minimally to $15.3 \pm 1.9 \mu \mathrm{mol} \cdot(\mathrm{kg}-\mathrm{min})^{-1} \quad(p<0.0003$ vs placebo]. In the Low Dose Group, there was a proportional decrease in the effects of Bay 27-9955 on these parameters.

Conclusion/interpretation. Bay 27-9955 is an effective and safe glucagon antagonist in humans. Given the potentially important role of glucagon in increasing glucose production and gluconeogenesis in patients with Type II (non-insulin-dependent) diabetes mellitus this agent could represent an innovative class of therapeutic agents for the disease. [Diabetologia (2001) 44: 2018-2024]

Keywords Glucagon, glucagon antagonist, glucose production, diabetes.
Fasting hyperglycaemia in patients with poorly controlled Type II (non-insulin-dependent) diabetes mellitus is closely associated with increased rates of glucose production which in turn can be ascribed to increased rates of gluconeogenesis [1-3]. While there

Received: 3 July 2001 and in revised form: 27 July 2001

Corresponding author: K. F. Petersen, Yale University School of Medicine, Department of Internal Medicine, P.O. Box 208020, New Haven, CT 06520-8020, USA,

e-mail: kitt.petersen@yale.edu

Abbreviations: GC-MS, Gaschromatography mass spectrometry; NMR, nuclear magnetic resonance. are many potential factors responsible for this higher rate of gluconeogenesis, increased portal vein concentrations of glucagon could play a role in this process $[4,5]$. Therefore, new therapeutic agents that are capable of blocking glucagon's effect on glucose production could be effective in lowering fasting hyperglycaemia in patients with Type II diabetes mellitus. Bay 27-9955 is a non-peptide compound that can be administered orally and competitively blocks the interaction of glucagon with the human glucagon receptor at an IC-50 value of $110 \mathrm{nmol} / \mathrm{l}$.

This study aimed to examine the anti-glucagonaemic effects of two doses of BAY 27-9955 in healthy volunteers under conditions of selective hyperglucag- 
Table 1. Safety data at baseline, study day 1 , day 2 and day 7 from high dose group (200 mg Bay 27-9955) (means \pm SEM). For reference normal laboratory values are given

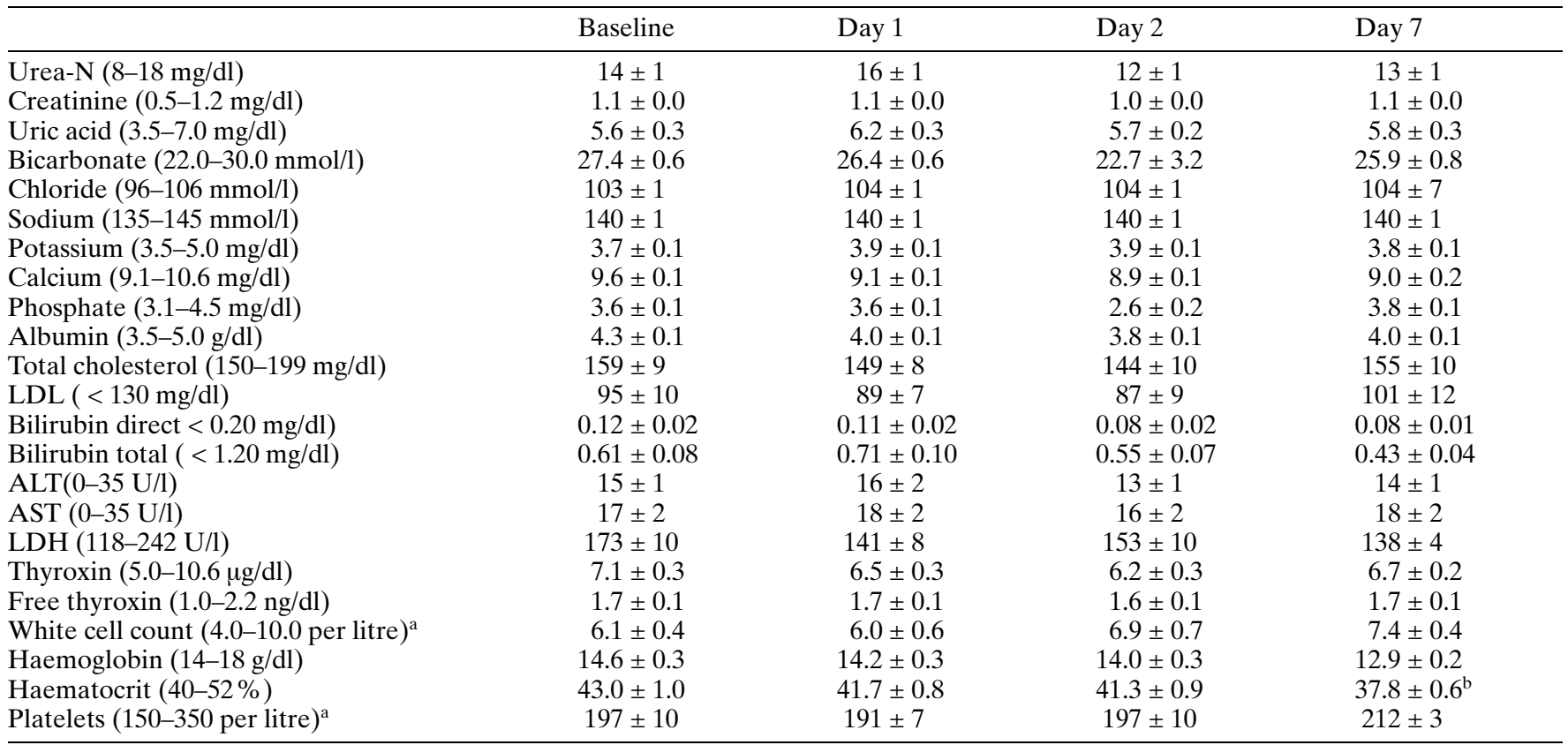

a $\cdot 10^{9}$

${ }^{\mathrm{b}}$ Not significant

onaemia and basal insulin concentrations. This was accomplished by infusing somatostatin to inhibit endogenous release of insulin and glucagon along with a constant infusion of insulin to replace basal insulin concentrations and glucagon to induce hyperglucagonaemia.

\section{Methods and materials}

Subjects. Fourteen healthy, lean, non-smoking men $(80 \pm 2 \mathrm{~kg}$, BMI: $25 \pm 1 \mathrm{~kg} / \mathrm{m}^{2}$, age: $24 \pm 2$ years) were recruited by advertisement. None of the subjects had a family history of diabetes, baseline fasting plasma glucose concentrations, glycosylated haemoglobin and $\mathrm{HbA}_{1 \mathrm{C}}$ were in the normal range and all patients tested negative for hepatitis $\mathrm{B}, \mathrm{C}$ and $\mathrm{HIV}$ infections. The study protocol was approved by the Yale University $\mathrm{Hu}$ man Investigation Committee and each volunteer gave their informed, written consent.

$B A Y$ 27-9955. The glucagon receptor antagonist (Bay 27-9955) [( + )-3,5 Diisopropyl-2- (1-hydroxyethyl)-6-propyl4'-Flouro-1,1'-biphenyl; $\mathrm{C}_{23} \mathrm{H}_{31} \mathrm{FO}$ ] (Bay 27-9955) is a white crystalline powder which is provided as a $90 \mathrm{mg} / \mathrm{dl}$ solution in a vehicle containing an unsaturated polyglycolyzed glyceride of apricot kernel oil. In this form it can be dissolved in warm water. Doses of Bay 27-9955 that were anticipated to provide prolonged exposure of concentrations greater than the IC-50 ( 1 and $3 \mathrm{mg} / \mathrm{kg}$ ) had previously been administered to healthy male volunteers in a single dose study designed to evaluate safety, tolerance and pharmacokinetics. Results demonstrated no safety issues and adequate drug exposure with a $\mathrm{T}_{\max }$ of approximately $2 \mathrm{~h}$. Fixed doses (rather than dosing per body weight) were selected since there were no identified toxicity in these dose ranges.
Study design. The study was conducted as a dose-dependent, double-blind, randomized, placebo controlled study and the first eight subjects who were recruited were given the highest dose of Bay 27-9955 (Group A: $200 \mathrm{mg}$ or $\sim 3 \mathrm{mg} / \mathrm{kg}$ ); the next six subjects were given the low dose of the drug (Group B: $70 \mathrm{mg}$ or $\sim 1 \mathrm{mg} / \mathrm{kg}$ ). On the day of the initial screening (Baseline), on the day of the study (Day 1), the day after (Day 2) and one week later (Day 7) of each part of the study fasting blood samples were drawn for determination of blood safety measures (Table 1 ). For 3 days before each study the subjects were given a standardized eucaloric diet consisting of regular food (60\% carbohydrate, $20 \%$ fat, $20 \%$ protein), prepared by the Metabolic Kitchen in the Yale University General Clinical Research Center (GCRC) Bionutrition Unit and they refrained from regular physical exercise. The subjects were admitted to the GCRC at $1700 \mathrm{~h}$ the day before each study, dinner was given at $1800 \mathrm{~h}$ followed by an overnight fast. At $0600 \mathrm{~h}$ the next morning (Day 1) Teflon catheters were inserted into an antecubital vein in each arm for blood collection and infusions. The time-course of the infusion study (Day 1) is shown schematically (Fig. 1). At $0700 \mathrm{~h}$ $(t=-180 \mathrm{~min})$ after collection of fasting basal blood samples, a primed $(5 \mathrm{mg} / \mathrm{kg})$ - continuous $(0.05 \mathrm{mg} / \mathrm{kg} / \mathrm{min})$ infusion of $\left[6,6-{ }^{2} \mathrm{H}\right]$ glucose (Cambridge Isotopes, Cambridge, Mass., USA) was initiated and continued throughout the infusion study in order to determine rates of glucose production. After a $180 \mathrm{~min}$ tracer equilibration period (zero min), blood was collected for the determination of plasma $\left[6,6-{ }^{2} \mathrm{H}\right]$ glucose enrichment and a single dose of $200 \mathrm{mg}$ (High Dose) or $70 \mathrm{mg}$ (Low Dose) of BAY 27-9955 or an inert placebo was given as a drink dissolved in sugar free, hot cocoa (Sugar free Swiss Miss, Hunt-Wesson, Fullerton, Calif., USA) to mask the bitter taste of Bay 27-9955. Then $2 \mathrm{~h}$ later (at the time of the anticipated maximal Bay 27-9955 plasma concentrations), at $t=0 \mathrm{~min}$, an infusion of somatostatin $\left[0.1 \mu \mathrm{g} \cdot(\mathrm{kg} \cdot \mathrm{min})^{-1}\right]$ (Bachem, King of Prussia, Pa., USA) was initiated to block endogenous release of insulin and glucagon. Basal insulin 


\section{Study protocol}

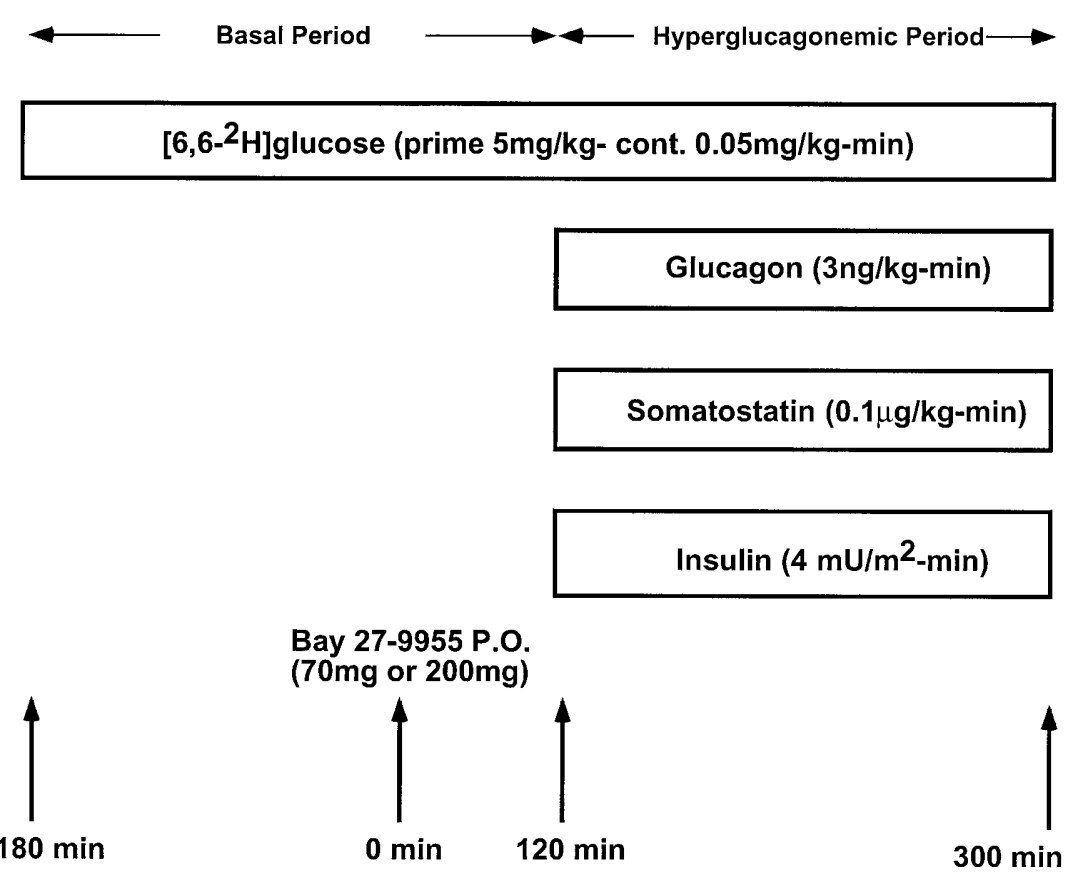

Fig. 1. Infusion study on day 1 shown schematically. Fasting rates of glucose production were measured after $180 \mathrm{~min}$ infusion of $\left[6,6-{ }^{2} \mathrm{H}\right]$ glucose. The glucagon antagonist, Bay 27-9955, was given at time $0 \mathrm{~min}$ and the $3 \mathrm{~h}$ period of selective hyperglucagonaemia was started at time $120 \mathrm{~min}$

concentrations were replaced by infusion of insulin at 24 $\mathrm{pmol} \cdot\left(\mathrm{m}^{2} \cdot \mathrm{min}\right)^{-1}$ and hyperglucagonaemia was attained by infusing glucagon (Eli Lilly, Indianapolis, Ind., USA) at a rate of $3 \mathrm{ng} \cdot(\mathrm{kg} \cdot \mathrm{min})^{-1}$ for $180 \mathrm{~min}$. At $t=300 \mathrm{~min}$ the infusions were terminated and the subjects were given a regular lunch followed by dinner (Fig.1). The subjects were admitted 3 weeks later for the second study, receiving BAY 27-9955 or placebo.

Blood collection. Blood samples for the determination of plasma glucose, insulin and glucagon concentrations and [6,6$\left.{ }^{2} \mathrm{H}\right]$ glucose enrichment were collected every $5 \mathrm{~min}$ during the last 20 min of the baseline period. After ingestion of the glucagon antagonist $(t=0 \mathrm{~min}$ ) blood was collected every $10 \mathrm{~min}$ to measure plasma glucose concentrations and $\left[6,6-{ }^{2} \mathrm{H}\right]$ glucose enrichment and every 15 min to determine plasma insulin and glucagon concentrations. Plasma concentrations of BAY 27-9955 were measured at time: 15, 30, 60, 90, 120, 150, 180 min after intake.

Safety data. At the time of the initial screening as well as on Days 1, 2 and 7 of each part of the study plasma $\mathrm{T}_{3}, \mathrm{~T}_{4}, \mathrm{TSH}$, uric acid, creatinine, nitrogen, ALT, AST, LDH, bilirubin (total and direct), $\mathrm{HbA}_{1 \mathrm{C}}, \mathrm{C}$-peptide, glycosylated haemoglobin, haemoglobin, haematocrit, white cell count, platelets, $\mathrm{Na}^{+}$, $\mathrm{K}^{+}, \mathrm{Cl}^{-}$, phosphate, bicarbonate, albumin were measured and urine analysis was done.
Analytical procedures. Plasma glucose concentrations were measured by the glucose oxidase method (Glucose Analyzer II; Beckman Instruments, Fullerton, Calif., USA). Plasma immunoreactive insulin and glucagon concentrations were measured using double antibody radioimmunoassay kits (insulin: Diagnostic, Webster, Tex., USA; glucagon: Linco, St. Charles, Mo., USA). Plasma glucose was derivatized as the pentaacetate, following $\mathrm{Ba}(\mathrm{OH})_{2} / \mathrm{ZnSO}_{4}$ deproteinization and semi-purification by anion and cation exchange chromatography (AG1-8X, AG50W-8X; Bio-Rad, Richmond, Calif., USA), as previously described [6]. A GC-MS analysis was done with a Hewlett-Packard 5890 gas chromatograph (HP-1 capillary column, $12 \mathrm{~m} \cdot 0.2 \mathrm{~mm} \cdot 0.33 \mu \mathrm{m}$ film thickness) interfaced to a Hewlett-Packard 5971A Mass Selective Detector operating in the electron impact ionization mode (Hewlett-Packard, Palo Alto, Calif., USA). For glucose-pentaacetate, GC analysis was isothermal at $200^{\circ} \mathrm{C}$. Selected ion monitoring was used to determine enrichment in various molecular ion fragments. [2$\left.{ }^{2} \mathrm{H}\right]$ glucose enrichment was determined from the ratio of $\mathrm{m} / \mathrm{z}$ 116 to 115 of the fragment consisting of $\mathrm{C} 2 \rightarrow \mathrm{C} 4 \cdot\left[6^{2} \mathrm{H}\right]$ glucose $\mathrm{m}+2$ enrichment was determined from the ratio of $\mathrm{m} / \mathrm{z} 202$ to 200 of fragment ion consisting of C2 $\rightarrow$ C6 [7]. Bay 27-9955 was measured by a validated assay using Liquid Chromatography/ Mass Spectrometry with a lower limit of quantitation of $1 \mu \mathrm{g} / \mathrm{l}$ (Bayer, AG).

Calculations. Basal rates of glucose production were calculated using the equations for steady state conditions as the $[6,6-$ $\left.{ }^{2} \mathrm{H}\right]$ glucose infusion rate divided by the average plasma [6,6$\left.{ }^{2} \mathrm{H}\right]$ glucose enrichment at steady state minus the $\left[6,6-{ }^{2} \mathrm{H}\right]$ glucose infusion rate [8]. During the hormone infusions, rates of glucose production and glucose disappearance $(\mathrm{Rd})$ were calculated using the Steele equations as modified by Radziuk for non-steady state conditions adapted for the use of $\left[6,6-{ }^{2} \mathrm{H}\right]$ glucose $[9,10]$. All rates are expressed in $\mu \mathrm{mol} \cdot(\mathrm{kg}$ body 


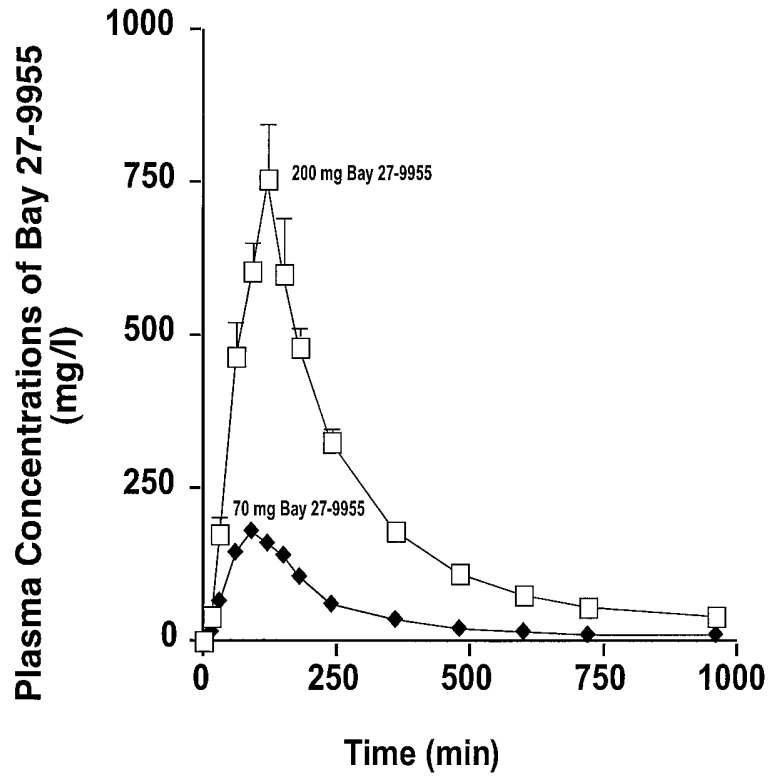

Fig. 2. Plasma concentration time profile for doses of 70 and $200 \mathrm{mg}$ of Bay 27-9955

weight $\cdot \min )^{-1}$. All data are presented as means \pm SEM. Comparison within subjects between placebo and glucagon antagonist studies were done using ANOVA with two-sided $p$-values of less than 0.05 being considered statistically significant.

\section{Results}

Plasma concentration of BAY 27-9955 increased rapidly to a peak of $751 \pm 106 \mu \mathrm{g} / \mathrm{l}$ at time zero when the hormone infusions were started. Thereafter, the plasma concentrations of Bay 27-9955 decreased to $180 \pm 19 \mu \mathrm{g} / \mathrm{l}$ by the end of the hormone infusions. In the low dose studies the peak concentration of Bay $27-9955$ was $160 \pm 13 \mu \mathrm{g} / \mathrm{l}$ also at time zero when the hormone infusions were started and by the end of the hyperglucagonaemic period the mean plasma concentration of Bay 27-9955 had decreased to $19 \pm 9 \mu \mathrm{g} / \mathrm{l}$. The mean plasma concentration of the glucagon antagonist decreased over the observation period of $48 \mathrm{~h}$ to $9 \pm 2$ and $1 \pm 1 \mu \mathrm{g} / \mathrm{l}$ in the high and low dose studies, respectively. On day 7 after administration there was no Bay 27-9955 detectable in either group (Fig. 2).

Bay 27-9955 was well tolerated and without metabolic or clinically important side effects. Furthermore, there were no significant changes in any of the safety parameters as measured on the initial screening day, Day 1, Day 2 and Day 7 of each part of the study (Table 1).

During the basal period plasma glucose, insulin and glucagon concentration were $5.2 \pm 0.1 \mathrm{mmol} / \mathrm{l}$, $42 \pm 12 \mathrm{pmol} / \mathrm{l}$, and $56 \pm 1 \mathrm{ng} / \mathrm{l}$, respectively. During the hyperglucagonaemic period plasma insulin concentration remained constant, plasma glucagon concentration rapidly doubled to $104 \pm 1 \mathrm{ng} / \mathrm{l}$ $(p<0.0001)$ (Figs. 3 and 4).
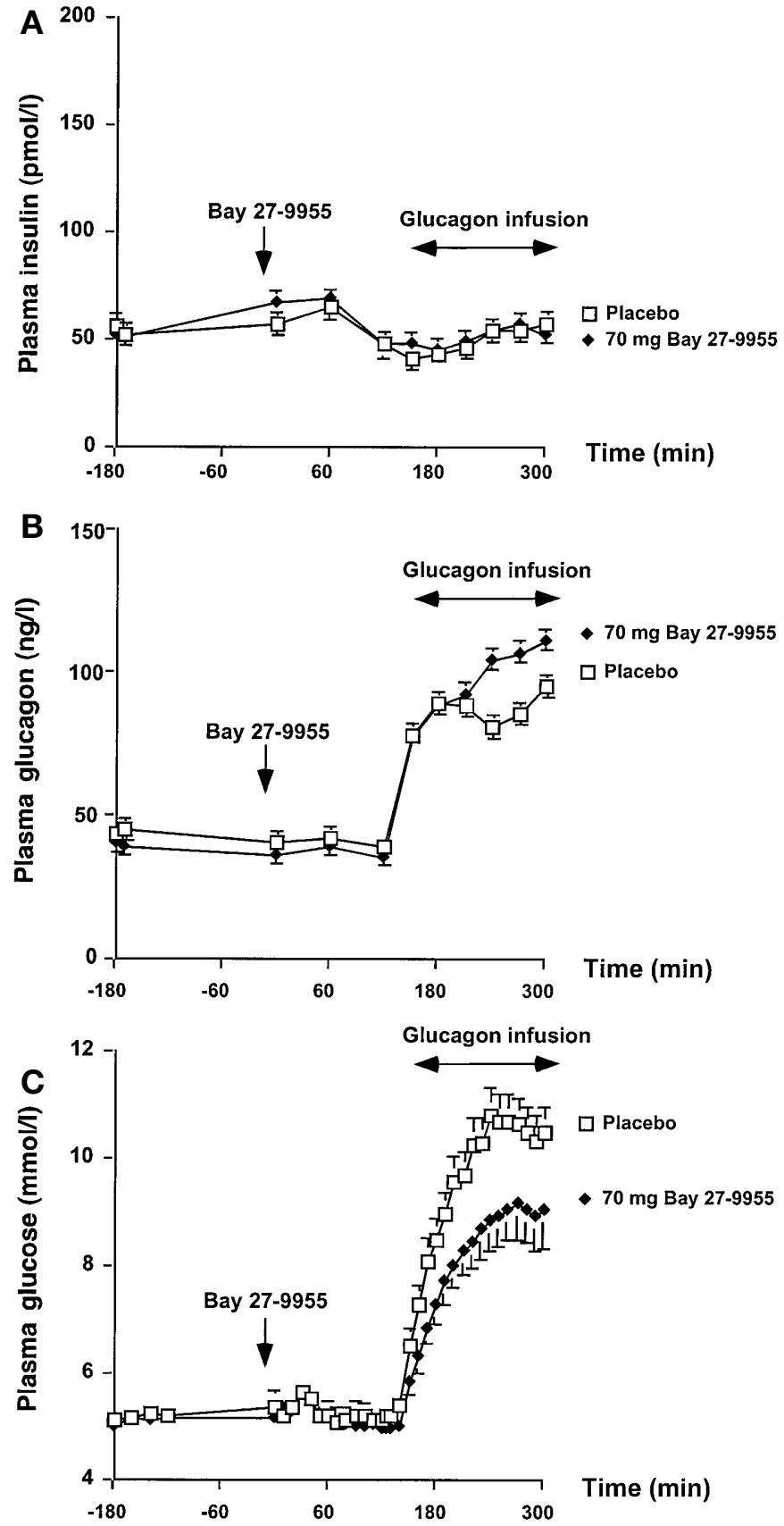

Fig. 3. Effects of low dose (70 mg Bay 27-9955) vs placebo on plasma insulin (A), glucagon (B) and glucose concentrations (C) at baseline and during selective hyperglucagonaemia

Low dose (70 mg Bay 27-9955) studies. In the low dose placebo studies, plasma glucose concentrations increased from $5.0 \pm 0.08 \mathrm{mmol} / \mathrm{l}$ to a peak of $10.8 \pm 0.5 \mathrm{mmol} / \mathrm{l}(p<0.0001)($ Fig. $3 \mathrm{C})$. The selective hyperglucagonaemia caused glucose production to increase by $103 \%$ from $11.2 \pm 0.2 \mu \mathrm{mol} \cdot(\mathrm{kg}-\mathrm{min})^{-1}$ to a peak of $22.7 \pm 2.3 \mu \mathrm{mol} \cdot(\mathrm{kg}-\mathrm{min})^{-1}(p<0.05)$ which subsequently decreased to $6.1 \pm 1.6 \mu \mathrm{mol}$. (kg-min $)^{-1}$ by 300 min (Fig. 5A).

There was a relatively modest effect of the low dose Bay 27-9955 on plasma glucose concentrations, which 

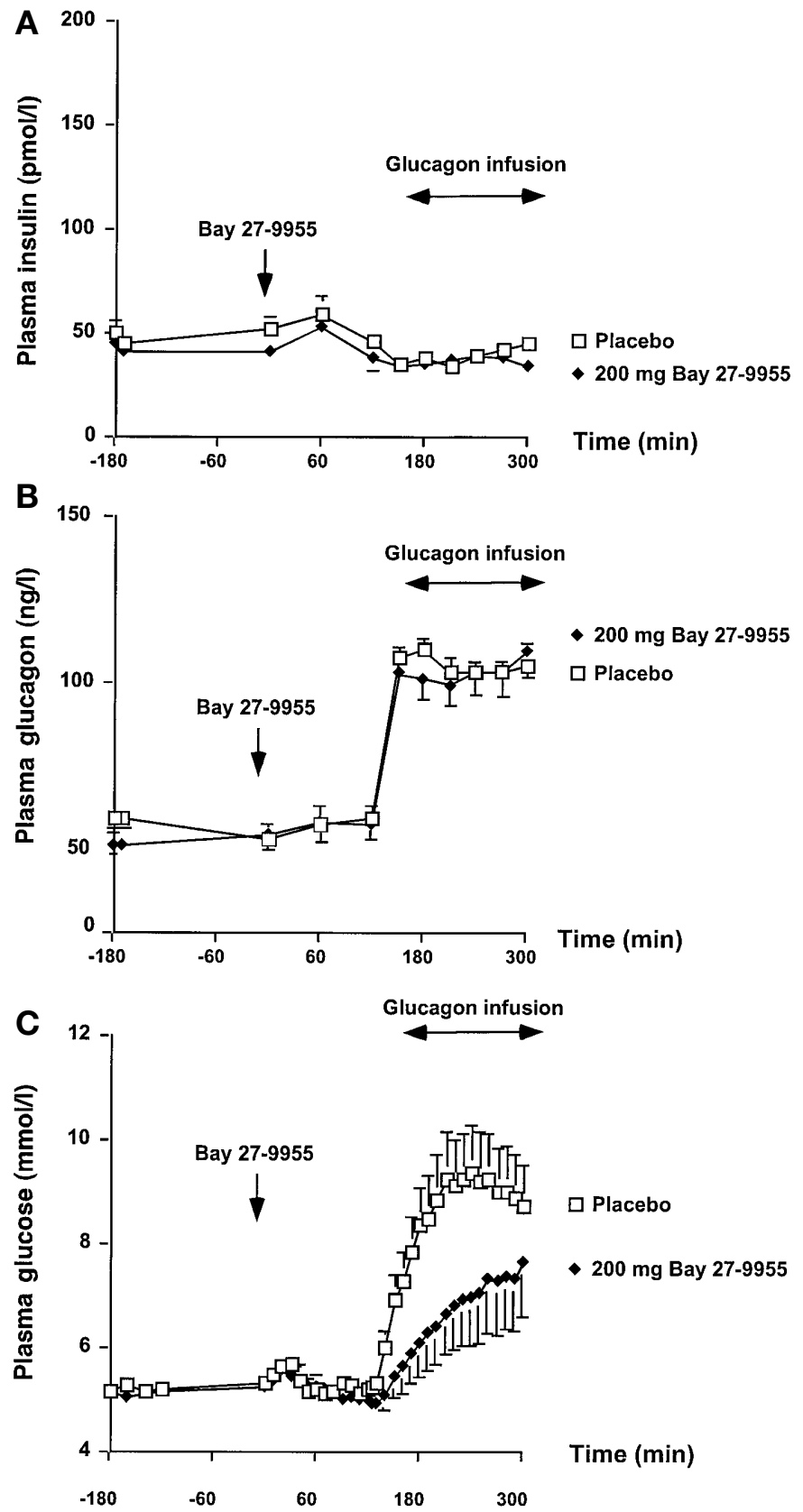

Fig. 4A-C. Effects of high dose (200 mg Bay 27-9955) compared with placebo on plasma insulin $(\mathbf{A})$, glucagon $(\mathbf{B})$ and glucose concentrations (C) at baseline and during selective hyperglucagonaemia

increased by $77 \%$ to $9.2 \pm 0.7 \mathrm{mmol} / \mathrm{l}(p<0.05$ vs basal) during the glucagon infusion. Rates of glucose production increased by $72 \%$ to a peak at $19.4 \pm$ $2.3 \mu \mathrm{mol} / \mathrm{kg}-\min (p=0.0382 \mathrm{vs}$ placebo $)$ and thereafter decreased to reach the low point of $5.3 \pm 1.2 \mu \mathrm{mol} /$ $\operatorname{kg}-\min (p=0.0439 \mathrm{vs}$ placebo) (Fig. 5A).

High dose (200 mg Bay 27-9955) studies. The timecourse for plasma insulin and glucagon concentrations are shown in Figure 4, A and B. Plasma insulin concen-

\section{A}

\section{Low Dose}

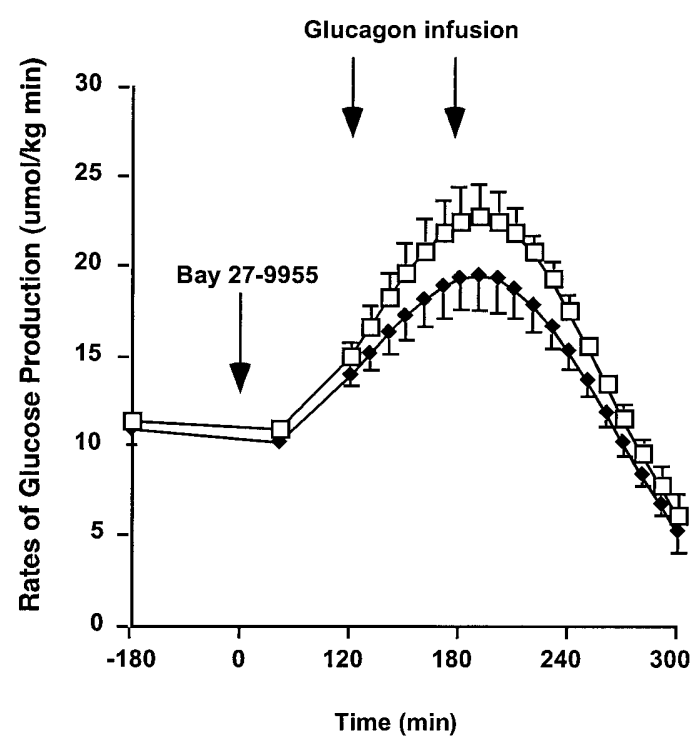

B

\section{High Dose}

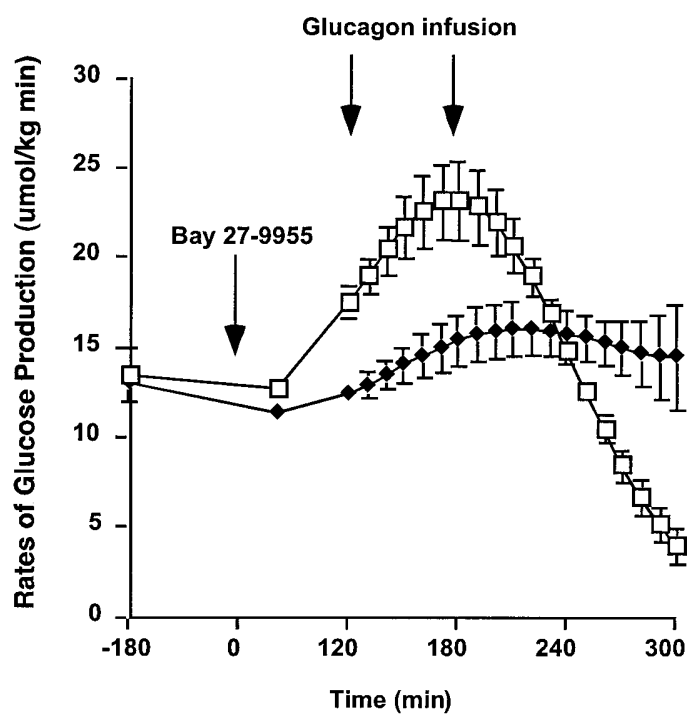

Fig. 5A, B. Rates of glucose production before and during selective hyperglucagonaemia after placebo $(\square)$ and low dose $(70 \mathrm{mg})$ of the glucagon antagonist Bay 27-9955 ( ) (A) and after placebo $(\square)$ and high dose $(200 \mathrm{mg}$ ) of Bay 27-9955 $(\bullet)(\mathbf{B})$

trations remained at basal levels throughout the studies and plasma glucagon concentrations doubled when the hormone infusions were started at $t=120 \mathrm{~min}$.

In the high dose placebo studies, plasma glucose concentrations peaked at $9.3 \pm 0.9 \mathrm{mmol} / 1$ by $240 \mathrm{~min}$ in the placebo studies and then declined to $8.7 \pm 0.8 \mathrm{mmol} / \mathrm{l}$ by the end of the hyperglucagonaemic period (Fig. 4C).

When the high dose Bay 27-9955 was given, plasma glucose concentrations remained constant at 
$5.2 \pm 0.1 \mathrm{mmol} / \mathrm{l}$ until the start of the hyperglucagonaemic period (Fig. 4C). During the hyperglucagonaemic period, the change in plasma glucose concentrations was blunted and there was only a small rise to $7.6 \pm 1.1 \mathrm{mmol} / \mathrm{l}(p=0.012 \mathrm{vs}$ placebo) (Fig. $4 \mathrm{C})$.

In the placebo studies glucose production increased promptly from $13.1 \pm 0.4 \mu \mathrm{mol} \cdot(\mathrm{kg}-\mathrm{min})^{-1}$ at baseline to a maximum of $23.2 \pm 2.6 \mu \mathrm{mol} \cdot(\mathrm{kg}-$ $\min )^{-1}$ at $180 \min (p<0.0001)$ and then gradually decreased to $4.0 \pm 1.4 \mu \mathrm{mol} \cdot(\mathrm{kg}-\mathrm{min})^{-1}(p<0.0001)$ by the end of the hyperglucagonaemic period at 300 min (Fig. 5B). In the High Dose Bay 27-9955 studies, the effects of the hyperglucagonaemia were blunted and glucose production increased by only $25 \%$ from $12.2 \pm 0.9 \mu \mathrm{mol} \cdot(\mathrm{kg} \mathrm{min})^{-1}$ at baseline to a peak of $15.3 \pm 1.9 \mu \mathrm{mol} \cdot(\mathrm{kg} \mathrm{min})^{-1}$ during the hyperglucagonaemic period ( $p<0.05 \mathrm{vs}$ basal; $\Delta$ glucose production $p=0.0003$ vs placebo) (Fig. 5B).

\section{Discussion}

Rates of basal hepatic glucose production are higher in patients with poorly controlled Type II diabetes and there is a strong correlation with the degree of fasting hyperglycaemia [11, 12]. Portal vein glucagon concentrations are inappropriately raised in these patients and could be an important contributing factor to the higher rates of gluconeogenesis [13]. The importance of increased plasma glucagon concentrations and basal hepatic glucose production Type II diabetic patients was first suggested by Unger at al. [13]. Other investigators studied the relation between hepatic glucose production and glucagon concentrations in control and Type II diabetic subjects. In the first set of studies in which both insulin and glucagon were suppressed by somatostatin, glucose production decreased by about $31 \%$ and plasma glucose concentrations decreased from $250 \mathrm{mg} / \mathrm{dl}$ to $190 \mathrm{mg} / \mathrm{dl}$ [14]. When basal insulin levels and fasting hyperglycaemia were maintained, the absence of glucagon caused glucose production to decrease by $58 \%$, indicating that the liver was quite sensitive to the combined effects of basal insulin and hyperglycaemia to suppress glucose production. They concluded that in patients with Type II diabetes, increased glucagon levels are largely responsible for hepatic insulin resistance and increased rates of glucose production [14]. Studies using ${ }^{13} \mathrm{C}$ nuclear magnetic resonance (NMR) spectroscopy to monitor directly hepatic glycogen content during an overnight fast, found that rates of net hepatic glycogenolysis decreased in patients with poorly controlled Type II diabetes and that increases in glucose production can be accounted for entirely by increased rates of gluconeogenesis [1,3]. Studies have examined the effects of hyperglucagonaemia on rates of net hepatic glycogenolysis and gluconeogenesis [2]. In these studies plasma glucagon concentrations were doubled by a $3 \mathrm{~h}$ infusion of glucagon while somatostatin was given to suppress endogenous release of glucagon and insulin, and a basal infusion of insulin was given to replace fasting plasma insulin concentrations. Rates of glucose production were measured with $\left[3-{ }^{3} \mathrm{H}\right]$ glucose and rates of net hepatic glycogenolysis and gluconeogenesis were measured with ${ }^{13} \mathrm{C}$ NMR spectroscopy. This study demonstrated that a doubling of plasma glucagon concentration caused a short-term doubling of rates of glucose production and that this increase could be mostly attributed to increased rates of net hepatic glycogenolysis. Although Type II diabetic patients have only moderately increased glucagon concentrations, even small changes in plasma glucagon concentrations have been shown to affect hepatic glycogen metabolism under insulin stimulated conditions [15]. In accordance with previous studies [2], the present study in healthy volunteers, showed that a two fold increase in plasma glucagon resulted in an immediate and short-term doubling of glucose production accompanied by significant hyperglycaemia. Subsequently, glucose production declined which was most likely due to the well known effect of hyperglycaemia in inhibiting glucose production $[16,17]$ as well as the waning effects of glucagon on glucose production [18] (Fig. 5). The glucagon receptor antagonist suppressed this hyperglycaemic response by blocking the glucagon induced increase in rates of hepatic glucose production in both doses administered, although the effects were less pronounced with the low dose $(\sim 1 \mathrm{mg} / \mathrm{kg})$ than with the high dose $(\sim 3 \mathrm{mg} / \mathrm{kg})$ (Figure 5). This dose response of hepatic glucose production to Bay 27-9955 is consistent with glucagon receptor antagonist exerting an effect through competitive receptor blocking which is almost complete at the highest dose. This is the first demonstration of an effective competitive glucagon antagonist in humans and represents a new potential therapeutic approach to the treatment of Type II diabetes.

Bay 27-9955 was well tolerated in this single dose study and there were no clinical side effects as reflected by absence of any deleterious effects on haematologic parameters, electrolytes, thyroid, kidney function or liver enzymes (Table 1).

In conclusion, these studies demonstrate that Bay 27-9955 effectively blocks glucagon-induced increases in glucose production and it is the first demonstration of an effective competitive glucagon antagonist in humans. Given the potentially important role of glucagon in promoting increased rates of glucose production in patients with poorly controlled Type I and Type II diabetes, this compound represents a new class of potential therapeutic agent for these diseases. Furthermore, this antagonist could help clarify the role of glucagon in maintaining normal physiologic contributions of glycogenolysis and gluconeogenesis to glucose production in healthy volunteers as well 
as clarifying glucagon's pathologic role in increasing rates of gluconeogenesis and hyperglycaemia in patients with poorly controlled Type II diabetes.

Acknowledgements. The authors would like to thank Drs. J.M. Amatruda, N. Livingston, and H. Reinhardt, Bayer Corporation for facilitating these studies and for helpful discussions. We thank Dr. A. Gastadelli for help with the non-steady state calculations. We also thank M. Gallentyne, Bayer Corporation, V. Walton, S. Vogel MPH, D. Casseria R.D., S. Page R. N., and the staff of the Yale - New Haven Hospital General Clinical Research Center for expert technical assistance with the studies. This work was supported by a Clinical Research Award from the American Diabetes Association (K.F. Petersen), grants from the Bayer Corporation and the United States Public Health Service: K23 (K.F. Petersen), RO1 DK-49230, P30 DK-34576 and MO1 RR-00125. The current address of J.T. Sullivan, MD, is Amgen, 1 Amgen Center Drive, Thousand Oaks, CA 91320-1799, USA. This work was presented at the annual meeting of the European Association for the Study of Diabetes (EASD), Brussels, Diabetologia Suppl. I, p A42, 1999.

\section{References}

1. Hundal RS, Krssak M, Dufour S et al. (2000) Mechanism by which metformin reduces glucose production in type 2 diabetes. Diabetes 49: 2063-2069

2. Magnusson I, Rothman D L, Gerard DP, Katz LD, Shulman G I (1995) Contribution of hepatic glycogenolysis to glucose production in humans in response to a physiological increase in plasma glucagon concentration. Diabetes 44: 185-189

3. Magnusson I, Rothman DL, Katz LD, Shulman RG, Shulman GI (1992) Increased rate of gluconeogenesis in type II diabetes mellitus. A $13 \mathrm{C}$ nuclear magnetic resonance study. J Clin Invest 90: 1323-1327

4. Raskin P, Unger RH (1978) Hyperglucagonemia and its suppression. Importance in the metabolic control of diabetes. N Engl J Med 299: 433-436

5. Unger RH, Aguilar-Parada E, Muller WA, Eisentraut AM (1970) Studies of pancreatic alpha cell function in normal and diabetic subjects. J Clin Invest 49: 837-848

6. Shulman GI, Cline G, Schumann WC, Chandramouli V, Kumaran K, Landau BR (1990) Quantitative comparison of pathways of hepatic glycogen repletion in fed and fasted humans. Am J Physiol. 259: E335-E341

7. Caprioli RM, Seifert WE (1973) Direct analysis of $18 \mathrm{O}$ in glucose by mass spectrometry. Biochim Biophys Acta 297: 213-219

8. Wolfe RR (1992) Radioactive and stable isotope tracers in biomedicine: principles and practice of kinetic analysis, Wiley-Liss, New York

9. Radziuk J, Norwich KH, Vranic M (1978) Experimental validation of measurements of glucose turnover in nonsteady state. Am J Physiol 234: E84-E93

10. Steele R, Bjerknes C, Rathgeb I, Altszuler N (1968) Glucose uptake and production during the oral glucose tolerance test. Diabetes 17: 415-421

11. Bogardus C, Lillioja S, Howard BV, Reaven G, Mott D (1984) Relationships between insulin secretion, insulin action, and fasting plasma glucose concentration in nondiabetic and noninsulin-dependent diabetic subjects. J Clin Invest 74: 1238-1246

12. DeFronzo RA, Ferrannini E, Simonson DC (1989) Fasting hyperglycemia in non-insulin-dependent diabetes mellitus: contributions of excessive hepatic glucose production and impaired tissue glucose uptake. Metabolism 38: 387-395

13. Unger RH (1970) The organ of Langerhans in new perspective. Am J Med Sci 260: 79-81

14. Baron AD, Schaeffer L, Shragg P, Kolterman OG (1987) Role of hyperglucagonemia in maintenance of increased rates of hepatic glucose output in type II diabetics. Diabetes 36: 274-283

15. Roden M, Perseghin G, Petersen KF et al. (1996) The roles of insulin and glucagon in the regulation of hepatic glycogen synthesis and turnover in humans. J Clin Invest 97: 642-648

16. Liljenquist JE, Mueller GL, Cherrington AD, Perry JM, Rabinowitz D (1979) Hyperglycemia per se (insulin and glucagon withdrawn) can inhibit hepatic glucose production in man. J Clin Endocrinol Metab 48: 171-175

17. Shulman GI, Lacy WW, Liljenquist JE, Keller U, Williams PE, Cherrington AD (1980) Effect of glucose, independent of changes in insulin and glucagon secretion, on alanine metabolism in the conscious dog. J Clin Invest 65: 496-505

18. Cherrington AD, Chiasson JL, Liljenquist JE, Jennings AS, Keller U, Lacy W W (1976) The role of insulin and glucagon in the regulation of basal glucose production in the postabsorptive dog. J Clin Invest 58: 1407-1418 